\title{
Reframing “Nuestra lengua” Transpacific Perspectives on the Teaching of Spanish in the Philippines
}

\section{Paula Park}

\author{
Wesleyan University, Connecticut, US
}

\section{Abstract}

Throughout the twentieth century, Spanish was increasingly marginalized in the Philippines, often characterized as the language of the colonizer, the language of the elites, or a backward language. While pro-Hispanists insisted that Spanish had great historical and symbolic value, this article examines the alternative ways in which Claro M. Recto (1890-1960) and Antonio M. Abad (1894-1970) defended its instruction in the Philippines. As a politician, Recto was well known for having supported the promotion of a common national language based on Tagalog. However, throughout his life, he maintained an intimate tie to the Spanish language, as evident in his recurrent return to his 1917 poem "Elogio del castellano," in which he elaborated on the global trajectory of the language. Even more so than Recto, Abad was a devoted defender of the dissemination of Spanish in the Philippines. This is apparent through his manuals and lectures on Spanish language pedagogy as well as his attendance at the Third Annual Congress of the Academies of the Spanish Language, which was held in Bogotá, Colombia, in 1960. By first examining Recto's poems and speeches, and then Abad's lectures and reports on the state of the Spanish language in the Philippines, this article argues that these two Hispanophone 
Filipino intellectuals, beyond merely highlighting the language's patriotic significance, sought to reframe the language as one that already belonged to Filipinos as well as to millions of people on the other side of the Pacific.

\section{Keywords}

Compulsory Teaching of Spanish, Pro-Hispanism, Common Language, Multilingualism, Cultural Diplomacy, Academies of the Spanish Language 


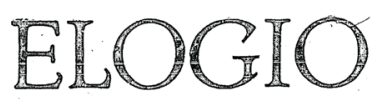

Consecuentes con el propósito de prestigiar a nuestra sangre y a nuestra raza, siempre hemos enaltecido el genio de España. Todo lo que exalte a la Madre Patria., tiene que reflejarse sobre las naciones americanas a las. cuales dio vida.

Por eso tenemos mucho gusto en reproducir la siguiente poesia, que mereció un premio extraordinario en los suntuosos Juegos Florales de Manila, y que le

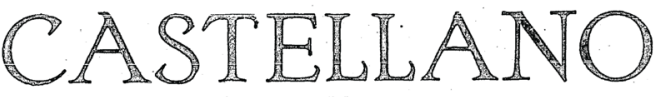

valió a su autor, el Señor Claro M. Recto, una ovación estruendosa.

Las Islas Filipinas se encuentran desde hace veinte años, sometidas al gobierno de los Estados Unidos; y es extraordinariamente consolador, ver que el espíritu español, en lugar de desaparecer en la patria de Aguinaldo, adquiere frescura y vigor y se impone con la fuerza de las cosas incontrastables.

"Ya no hay nobles hidalgos, ni bravos caballeros? ¿Callaremos ahora para llorar después?

\section{RUBEN DARIO._- "Los Cisnes"}

Arca Santa inviolable de la Raza, Arca Santa de próceres leyendas, que a tu prestigio espiritual vinculas la gioria de las magnas epopeyas; Arca egregia y divina, que en las ingentes luchas ya pretéritas sobreviviste al colonial desastre, cual sobrevive el alma a la materia; Arca ebúrnea, copón de maravillas, donde se guarda secular herencia; Arca de lo inmortal que veneramos en la vetusta casa solariega; Arca de oro que ofrece el Libro Santo y el perfumado Pan de la Belleza, por quien juramos proscribir la casta de osados malandrines que te afrentan; la musa tropical, la musa autóctona, de tus clásicos lauros heredera, torna a pulsar el clavicordio hispano, clavicordio romántico que sueña, clavicordio que sufre como una alma, clavicordio polífono que encierra en sus notas lo grande, clavicordio donde llora sus cuitas Filomela, donde estallan los gritos del combate, donde retumba la canción de gesta. Y canta en tu loor, ; oh lengua hispana! del pensamiento alada mensajera, que fulguras, cual límpida custodia de la Eterna Verdad, en las conciencias, como el Sol en las cúspides altivas donde la tromba y el ciclón fermentan, como el anhelo indígena que fulge en el blasón astral de mi bandera.

¡Oh lengua sacrosanta de Fray Luis y Miguel, Lope de Vega del Arcipreste, Calderón y Góngora,

los Argensola, Hurtado y Espronceda ¡oh lengua que enfíoró de madrigales las pristinas edades romancescas, toda hecha de vorágines $y$ truenos, toda hecha de suspiros y cadencias, coro inmenso de tímpanos, concierto de las panidas flautas en la sierra, sinfonía fantástica que irrumpe del arpa gigantesca de las selvas.

Es tu ritmo la ronda bulliciosa de crótalos y locas panderetas, de guitarras que dicen el elogio de unos ojos reidores que asaetan; es la rișa que en notas se desata cual cristalino desgranar de perlas, el madrigal sonoro que desiíe sus estrofas de amor en las verbenas, y el chocar de las copas musicales donde hierve la 'sangre de las cepas.

Es tu acento el susurro que adormecê del aura al retozar en la floresta, y el blando caramillo que solloza bajo el beso lunar, en primavera. Te remeda el gorjeo de la alondra, la imperativa voz de las trompetas, el quejido que emerge de la cuna y el doliente "kundiman" de mi tierra; el raudo vendaval que avanza indómito por cima de las altas cordilleras, y brama en los barrancos y hondonadas $y$ en las rocas que hendieron las centellas.

$\mathrm{Y}$ tuviste en la lira de Quintana ecos triunfales, resonancias bélicas de estoques y corazas y armaduras que son el timbre perennal de Iberia; en los versos broncíneos de Chocano fragor de sordas cataratas épicas, algazara de pompas coloniales, rumor de besos y temblor de quenas. De Solís, en la prosa cincelada impetus de corcel, dianas homéricas, estrépito de lanzas y tizonas, de broqueles y cascos y rodelas. En Fray Luis de León fuiste cigarra que endulzaba el reposo de la siesta, y tonada de amor de la tierruca en los cuadros agrestes de Pereda. Caballero gentil de la Armonía en el rugiente "Niágara" de Heredía, batir de alas de ingrávidos querubes en las frovas ardientes de Teresa. $\mathrm{Y}$ en el arpa divina de Darío ruído de encajes y frufrús de seda, música de cinceles sobre el mármol y murmurio de risas $y_{0}$ de gemas; canción de cisnes sobre cl quieto estanque al paso de las "púberas canéforas," arpegios de los violines cortesanos y vibración de cítaras helenas......

Fig. 1. Recto's poem appeared in Revista Mexicana: Semanario llustrado on April 22, 1917. Image digitized by Hemeroteca Nacional de México. 
Y cerraste la elipse de tu gloria, con un estruendo de imperial proeza, en las perennes páginas altísimas del libro de Cervantes Saavedra.

No en vano fueron por ignotas mares de Hispania las veloces carabelas en comunión ferviente con la Audacia y los a tos designios de la Idea; no en vano los Cortés y los Balboa desafiaron el hambre y las tormentas, y sus bridones épicos midieron las pampas infinitas de la América; no en vano sobre el pico de los Andes, dueña del mundo, flameó tu enseña, tan amplia que cubrió los continentes, tan goriosa, tan noble y tan excelsa; no en vano por tres siglos tus ejércitos han levantado en mi solar sus tiendas, $y$ vieron el prodigio de mis lagos $y$ de mis bellas noches el poema; no en vano en nuestras almas imprimiste de tus virtudes la radiosa estela, y gallardos enjoyan tus rosales penos de aroma las nativas sendas: tu imperio espiritual vive y perdura, y extiende su simbólica cadena del Pirene a los Andes y al Carballo, y en un abrazo inmenso los estrecha. Por los mares At lántico y Pacífico tus fuertes galeones aun navegan y van en ellos, bajo un sol de gloria, almas grandes que luchan y que anhelan, Andarites Caballeros del Ensueño, guardianes de la fe de Dulcinea locos sublimes que descubren mundos y mueren por su reina, la Quimera. Aun nos ofrecen tus antiguos códices ta fórmula inmortal de la Belleza, $\mathrm{y}$ tus filtros $\mathrm{y}$ alquimias prodigiosos del humano dolor la panacea.

No morirás jamás en este suelo que ilumina tu luz. Quién lo pretenda ignora que el Castillo de mi Raza es de bloques que dieron tus canteras.

\section{E N V I O :}

Casa de España, Olimpo de las Artes, Templo del Porvenir, ¡bendita seas! Las musas danzarán sobre tu césped y gustarán la miel de tus colmenas. Sé el manantial donde las almas nobles el agua pura del Ensueño beban la Torre de marfi! donde se guarde el tecoro ideal de nuestra lengua. Hispanos: si a'gún día la escarnecen, nuestras aljabas vaciarán :sus flechas, y ros verán, triunfantes o vencidos, al pie de esta sagrada ciudadela.

CLARO M. RECTO.

21 de Enero de I9I7.

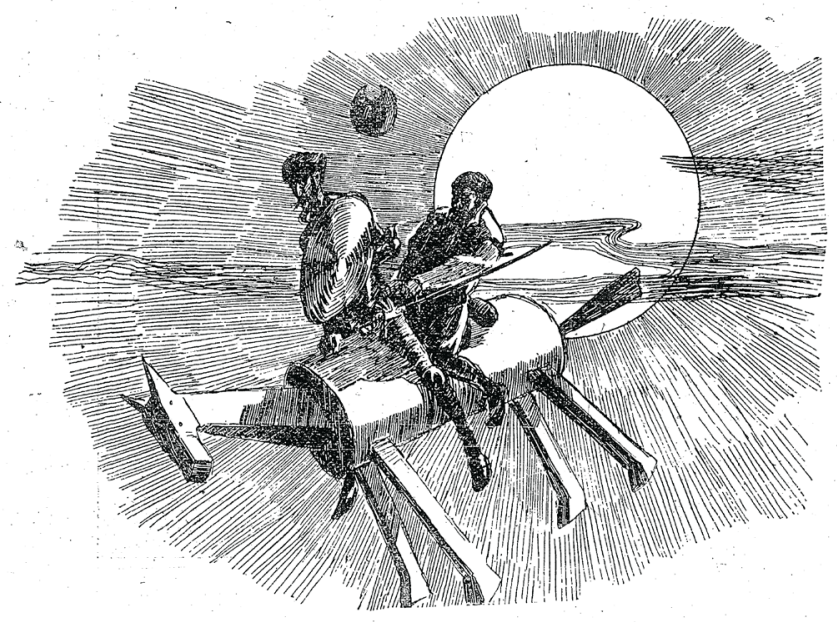

Fig. 1. (cont'd.) Recto's poem appeared in Revista Mexicana: Semanario llustrado on April 22, 1917. Image digitized by Hemeroteca Nacional de México. 
DICIADA POR EL PROFESOR ANIONIO M. AZAD, EX-JEHE DEI DEPAR AIGTYO DE ESPANOOL DE LA

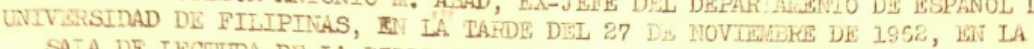
SA'A DE IECTURA DE IA BISLIOTECA DE IA SOEIDARIDAD FILIPINOEISFANA

En la tarie del 27 de novionbre de 1962, y axbe un público selecto y distinguido, don Antonio M. Auad, antiguo jefo (hoy jubilado) del Departenento de Espariol de la Universidad de Filipinas, dictó le siguiente conforencie:

\section{IA BINSETATIA DEL ESPANTOL EN IILIPINAS -- SUS MAIES Y SUS RHMEDICS --}

Después de oir on esta sala la cxposición do interesantes asuntos que efortan al hombre en generel, os hor de volver los ojos hacia nuestros propios y más directos problomas pare trutarlos y oncarnrlos con la méxi na objetividad. Annlizados y estudiados sill pasión, os justo que soñalonos los medios con los curles gueromos llogar a una solución, marenncio en tal caso los pesos ques debemos dar para orientar nuostra actividad hacia la consecución de nuestros objotivos.

No ostamos opuestos a la cultura indízena

Por monos sólito que parozca, trateremos de nuestros fines como de un ante todo para que ellos nos digan si nuestra activiciad os proporcional a ellos. Digenos on soguida que el objetivo prinoldial del hispanismo filipino es la conserveción dol español en Filipinas, porque extendomos que sólo por ella puede pervivir la cultura hispénica en nuostro pais, cultura que se sirvo precisamente del lengunje cono de su vohículo principal de propngoción.

Fig. 2. Abad's 1962 lecture on the teaching of Spanish in the Philippines. Copy housed at the Library of Instituto Caro y Cuervo, Colombia 
¿Seremos entregados a los bárbaros fieros?

¿Tanto millones de hombres hablaremos inglés?

-Rubén Darío, Cantos de vida y esperanza (1905)

In a series of lectures held at the University of the Philippines in 1979, award-winning prolific author Federico Espino Licsi called upon Filipinos to read more Latin American literature. ${ }^{1}$ Filipinos, he argued, needed to become more acquainted with the revolutionary or "anti-gringo" works of Cuban José Martí, Chilean Pablo Neruda, Argentine Ernesto "Che” Guevara as well as "otras voces líricas de la parte del Tercer Mundo en donde se habla el idioma iberoamericano" (18). Interestingly enough, Espino Licsi referred to these writers' medium of expression as an "Ibero-American"-instead of a European, Western, and colonial-language. However, he was far from advocating that their works be read in their original Spanish. That is, he did not articulate a defense of Spanish; rather he opted for more translations of these writings into "our cradle tongue" (19). ${ }^{2}$ In regard to the teaching of Spanish in the Philippines, Espino Licsi observed:

Many Hispanista friends of mine will disown me when they hear my speech this morning. They will probably say I do not deserve the Premio Zobel or the Fernando Ma. Guerrero Award for Literature or even the prize I won in Spain. But there are times when friendship should be set aside. Gaya ng marahil ay alam na ninyo, ako'y makatang sumusulat sa Pilipino, sa Ilokano, sa Inglés, at sa Kastila nguni't hindi ako sang-ayon sa sapilitang pagtuturo ng Kastila sa mga pamantasan dito. Es una especie de neocolonialismo. (18-19)

To be clear, the poet was not exactly making an attack on the dissemination (or perhaps survival) of Spanish in the Philippines. His was an insistent call for more translations into the vernacular languages of the Philippines, hence greater appreciation for linguistic diversity as well as a claim against the compulsory teaching of Spanish. ${ }^{3}$ Nevertheless, Espino Licsi proceeded to refer to Spanish as "idioma del colonialista," "lenggwahe ng kolonisador" (21). Moreover, clarifying his support of multilingualism, he declared at the end: "Bago unawain ang Babel ng iba, / Sariling Babel ay unawain muna. (Antes de aprender el Babel extranjero, / Hay que aprender el Babel nuestro)" (21), thereby 
implicitly excluding Spanish as a language that belonged to Filipinos. The characterization of Spanish as the colonizer's language may seem passé but in this context it makes us wonder: why did Espino Licsi leave Spanish, a language he dominated fairly well and often employed as a poet, out of his definition of "el Babel nuestro"? " To answer this question, it is worthwhile to go back in time and consider how Spanish was taught in the Philippines throughout the twentieth century.

Historians agree that after 333 years of Spanish rule, only a minuscule percentage of Filipinos were fluent in Spanish. ${ }^{5}$ Exact statistics from the end of this period vary widely, but they generally confirm that Spanish did not reach the masses, at least not as mandated by the Education Decree of 1863, which had sought to provide free and compulsory education in Spanish to all children from age seven to twelve. ${ }^{6}$ In Noli me tangere (1887), José Rizal fictionalizes some of the possible reasons for the dire results of this decree as his protagonist Juan Crisóstomo Ibarra, back from his sojourn in Europe, visits a parochial school in Central Luzon and strikes up a conversation with a teacher. The latter tells Ibarra that students are forced to memorize passages or even entire books in Spanish, "sin entender de ellos una palabra" (98). Rejecting this method, the teacher tries out a new approach: one based on interaction and transmission of meaning, rather than memorization. While this practice proves to be quite effective (the teacher tells Ibarra that slowly, but surely, students were able to understand him and eventually articulate phrases of their own in the language), the Spanish friars who run the school force him to stop, arguing that Spanish is not for Filipinos. ${ }^{7}$ This scene illustrates how the dissemination of Spanish, beyond the memorization of Christian doctrines, was a threat to the friars, "a challenge to their authority and a veritable theft of their privileges" (Rafael 26), as knowledge of the language could potentially give Filipinos access to liberal anticlerical writings. Spanish, as a living language, did not belong to Filipinos.

Shortly before and after becoming independent from the Spanish Empire, publications in Spanish flourished, giving rise to what critics often refer to as the Golden Age of Philippine literature in Spanish. However, this literary outburst was interrupted when the United States government 
quickly imposed English as the lingua franca of the Philippines. Already in 1901, English was established as the sole language of instruction in public schools and to enforce this rule, hundreds and eventually thousands of teachers from the United States were sent to the Philippines (Fernández 373). In this respect, the United States was able to assume the role of the responsible and caring provider, the educator of the Filipino people, while conveniently promoting the centuries-old black legend of Spain as a cruel and selfish tyrant. Despite its historical and foundational value in the Philippines, Spanish was set to become a language mastered by fewer and fewer Filipinos.

During the first phase of the American colonial period (1898-1935), Spanish and English were the co-official languages for civil service. As conversations on adopting a national common language based on a vernacular language emerged in the 1930s, Spanish began to lose even more ground. In 1934, the Tydings-McDuffie Act excluded Spanish entirely from the curriculum of public schools (Recto, vol. 7, 114-15). In preparation for the Commonwealth government, the Constitutional Convention met that same year and recommended that Spanish continue as one of the official languages of the legislature and of the courts, but only up to 1940 (Gonzalez 50). The expiry date for Spanish was set. Accordingly, in 1940, Commonwealth President Manuel L. Quezon claimed: "I believe we should have this national language rather than English or Spanish, and because I know that we can never make English or Spanish-certainly not Spanish-the national language of the Philippines" (my emphasis, 25). And "certainly not Spanish" was the general inclination of Filipino intellectuals and politicians in debates for the lingua franca of the Philippines after the Commonwealth period. Nevertheless, in 1947, Spanish was re-introduced under the Sotto Law (Republic Act No. 343). Although the original bill had intended to render it compulsory, it reentered the curriculum as an optional course. In 1952, the Magalona Law (Republic Act No. 709) made Spanish compulsory for two consecutive years in all universities and private schools. The Cuenco Law (Republic Act No. 1881), approved in 1957, required twenty-four credits in Spanish for Education, Law, Trade, Liberal Arts, and Foreign Service. 
All of these bills generated heated public debates and Spanish became an unpopular requirement for Filipino students. As a result of student protests, in 1967, under Republic Act No. 5182, the number of required credits in these university concentrations was reduced by half. ${ }^{8}$ Meanwhile, Spanish remained in usage in various official contexts even though it was virtually left out of debates on what the national language should be in the future.

By the seventies, Spanish continued to be taught in schools, but as if it were a foreign-or rather, a dead-language, following a methodology largely based on the memorization of rules and conjugations (Donoso and Macahilig-Barceló 421). Students knew Rizal and his poem "El último adiós," but they knew it, ironically, mirroring how school children in Noli me tangere studied Christian doctrines: regurgitating lines they barely understood. After a trajectory of marginalization, in 1987, Spanish ceased being an official language of the Philippines. Isaac Donoso summarizes the stigmatization of Spanish throughout the twentieth century like this: "de lengua nacional en 1898 a lengua elitista en 1945, o, peor, lengua de la leyenda negra y del aburrimiento en 1987" (432).

In what follows, I want to explore alternative ways in which two Hispanophone intellectuals, poet-turned-politician Claro M. Recto (18901960) and novelist and educator Antonio M. Abad (1894-1970), sought to refashion the teaching of Spanish in the Philippines. Instead of lingering on ovations to the language, which often morphed into unapologetic longings for the bygone Spanish Empire, they tried to disentangle Spanish-language instruction from a colonial impetus ruled by imposition and turned their focus to the language's vitality across the Pacific in Spanish America.

\section{"Por los mares Atlántico y Pacífico": Recto's Unending Affair with the Spanish Language}

In the first decades of the twentieth century, various Hispanophone Filipino writers were generally alarmed by the overwhelmingly rapid rate at which Filipinos were being Americanized. As a result, they took refuge in the Spanish language and evoked the past Spanish Empire. For instance, in a poem written in honor of Spanish writer Salvador Rueda who visited 
Manila in 1915, a young Claro M. Recto exalted the "spiritual," "generous," and "immaculate" Spain. Several lines of this poem, titled "Mi homenaje a la matrona," are devoted to the "divine" Spanish language. He hails from the former colony:

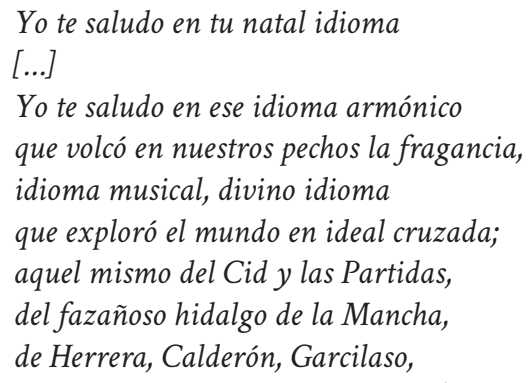

The Spanish language here is not presented as one that belongs to Filipinos, but rather to a long list of Spanish writers, including his interlocutor, Salvador Rueda. Later in the poem, Recto dares to appropriate the Spanish language, but only indirectly, by claiming that it is also indeed the same language employed by Rizal and in the first constitution of the Philippines.

In "Elogio del castellano," a poem from 1917, Recto offers a more elaborate praise for the Spanish language. Written for the inauguration of "Casa de España," the poem is on the surface virtually indistinguishable from "Mi homenaje a la matrona" or other poetic homages to Spain or the Spanish language. "Arca Santa," "Arca egregia y divina," and "Arca de oro" are some of the pompous epithets for the language of Fray Luis de León, Cervantes, Lope de Vega, Calderón, Góngora, and other writers of the Spanish Golden Age (vol. 1, 287-88). Yet what calls our attention even before the opening litany is the poem's epigraph, two lines by Nicaraguan writer Rubén Darío: “ ¿Ya no hay nobles hidalgos, ni bravos caballeros? / ¿Callaremos ahora para llorar después?" (vol. 1, 287). These lines come from Cantos de vida y esperanza (1905), a collection in which Darío summons Spanish Americans-or "the mil cachorros sueltos del León español” (104), as put in his emblematic poem "A Roosevelt"-to unite against the looming expansion of the United States 
in Latin America. ${ }^{10}$ Darío was not really inclusive of Filipinos in his call, yet the lines immediately preceding those quoted in "Elogio del castellano" unveil a preoccupation that would be much more pressing in the Philippines than in Latin America: “Seremos entregados a los bárbaros fieros? ¿Tanto millones de hombres hablaremos inglés?" (109). Framed like this, Recto's deep concern about the Americanization of the Philippines has a lot in common with the fear of Latin American intellectuals at the turn of the twentieth century. The epigraph also signals that Recto might have read Spanish Golden Age writers alongside Spanish American literature. And indeed, throughout the rest of his poem, Recto evokes the lyres of Spanish author Manuel José Quintana and Cuban Romantic writer Juan María Heredia; before invoking Fray Luis again, he summons the "bronze verses" of Peruvian José Santos Chocano; Cervantes and Santa Teresa de Jesús resound in conjunction with Darío's "divine harp" (vol. 1, 289). Put differently, Recto interweaves literary references from both sides of the Atlantic, revealing an affinity not only to Spanish writers, as in the case of his earlier "Mi homenaje a la matrona," but also to Spanish American poets.

The last sections of "Elogio del castellano" feature the spread of the language across the Atlantic and foremost throughout Latin America: in the "vírgenes pampas de la América" and "lo alto de los Andes" (vol. 1, 289). Thus, Recto reassures that the global trajectory of the Spanish language will not come to an end in the Philippines. Invoking the transatlantic and the legendary Manila-Acapulco galleon trades, he asserts:

Por los mares Atlántico y Pacífico tus fuertes galeones aún navegan $y$ van en ellos, bajo un sol de gloria, almas grandes que luchan y que anhelan, Andantes Caballeros del Ensueño, Guardianes de la fe de Dulcinea, Locos sublimes que descubren mundos Y mueren por su reina, la Quimera. (vol. 1, 290)

Recto neither thanks nor praises Spain for giving him or lending him the Spanish language. Rather, he historicizes it and then appropriates it. After 
all, Spanish is, in his own words, "nuestra lengua" (vol. 1, 290). The implied "nosotros" in the poem, considering the occasion for which it was written, refers, without a doubt, to Spaniards and Filipinos. However, when taking into account the entirety of the poem, the "nosotros" is also inclusive of Spanish Americans.

According to critic Wystan de la Peña, "by the 1930s, to speak Spanish, to be 'Fil-Hispanic' meant being old-fashioned; to speak English, to be 'Americanized,' meant being modern” (105). By then, even Recto had bid farewell to the Spanish language and to his career as a poet and playwright, devoting himself to his political career. ${ }^{11}$ His fight for the independence of the Philippines from the United States intensified and he became, in his own words, an "enthusiastic advocate of the use of Tagalog as the most practical medium of national expression” (qtd. in Gonzalez 80). In 1942, as Commissioner of Education, Health and Public Welfare, Recto encouraged Filipinos to support the cause of employing Tagalog as a common language and to even be open to learning Japanese, which was momentarily declared an official language. ${ }^{22}$ After the independence of the Philippines, Recto continued supporting efforts to make Tagalog the basis of the national language. Nevertheless, he was still intimately tied to Spanish. Recto kept his membership in the Philippine Academy of the Spanish Language and as observed by historian Augusto Espiritu, even as a politician, he remained "involved with the promotion of Spanish in the Philippines, either as a judge of literary contests, or through acquaintance with the Spanish government in the Philippines" (169). For example, in 1953, he gave a speech at a banquet in honor of the Minister of Foreign Relations of Spain, during which he took the opportunity to declare the need to maintain the Spanish language, which he characterized as the greatest benefit within Spain's "spiritual legacy." Recto foresaw that Spanish would never become a popular language among Filipinos, yet he also declared it an irreplaceable vehicle to understand the nation's history in the future. At this point, Recto disassociated the Spanish language and the Philippines' sense of Hispanism from Spain: 
nuestro hispanismo, en punto a finalidad, y como aspiración y propósito, nada tiene que ver con España, sino con nosotros mismos, porque el español, por cuya conservación y difusión luchamos, que a todo se reduce a fin de cuentas nuestro hispanismo, es algo que ha llegado a ser nuestro, propio, consustancial, por fuero de historia $y$ de espiritualidad, por razones de presente y por exigencias del futuro, $y$ sin él quedaría grandemente menguado el inventario del [sic] valores de nuestro patrimonio cultural, y descoyuntada, como un cuadro cubista, toda prefiguración del futuro de nuestra nacionalidad. (vol. 7, 490)

According to Recto, the burden of conserving the Spanish language in the Philippines must rely on Filipinos alone. Nevertheless, he also identified yet another reason to keep ties with the language: to strengthen diplomatic bonds with Spanish American nations, which occupy more than one third of the entire United Nations (vol. 7, 491). Spanish, following Recto, could thus link the Philippines to the rest of the world. Along those lines, it is worthwhile mentioning that to conclude his lecture, Recto read the last sections of his poem "Elogio del castellano," emphasizing in this manner the global trajectory of the language.

In retrospect, it is easy, or perhaps tempting, to see Recto as a strong proponent of the preservation of Spanish in the Philippines, especially if we consider that until 1960, the year he suddenly died, he insisted that Filipinos would benefit from learning the language. Indifference toward the language, Recto laments in "La cruzada por el español en Filipinas," one of his last undelivered speeches, had evolved into a desertion of the language (vol. 9, 722). Echoing his 1953 speech, he adds here that Latin Americans in the United Nations rejoice when they hear Filipinos speaking "en su propio idioma" (vol. 9, 724). In another undelivered speech, titled "Por los fueros de una herencia," Recto includes yet another similar comment regarding the possibility of striking an intimate chord with Latin American diplomats in the United Nations (vol. 9, 756). This speech also contains a poem titled "Elogio del idioma," which like his earlier "Elogio del castellano," traces the Spanish language's arrival to the Philippines by way of the Pacific: from Spain "al corazón de América / y hasta a mis bravas tórridas campiñas" (vol. 9, 759). Recto seemingly wanted to connect with Latin Americans, but the 
opportunities to do so, for him, were limited. In 1960, Recto was scheduled to tour Spain and Latin America; however, he died in October of that year. ${ }^{13}$ We can only imagine how these trips would have modified or further rekindled the pro-Hispanist cause of Hispanophone Filipino intellectuals through Recto. Yet instead of imagining what could have been, we can turn to Recto's colleague in the Philippine Academy of the Spanish Language, Antonio M. Abad, who only a few months earlier, in July 1960, did travel across the Pacific, established contacts with Spanish American intellectuals, and with their support, managed to revitalize the teaching of Spanish in the Philippines.

\section{"Formar parte del grupo hispanoamericano":}

\section{Abad on Teaching Spanish as a Foreign and a Filipino Language}

From early on in his career as a writer and educator, Abad perceived the Spanish language not only as a means to access the nation's past and origins, but also as the Philippines' link to the world by way of Spanish America. ${ }^{14}$ Critic Salvador García rightly observes: "No sólo se trataba de luchar por impedir la muerte de un idioma, sino de fomentar además la lengua que haría a los filipinos reconocerse como tales, hallar su esencia, hermanarse con sus semejantes, con aquellos pueblos que sueñan y viven y aman en español" (xxix). When Abad joined the Philippine Academy of the Spanish Language in 1938, he gave a speech in which he claimed that the destiny of Spanish in the Philippines had been "truncated," but had to be fulfilled as it did in Spanish America (qtd. in García xv). Put like this, it seems as if Abad saw in Spanish America a sort of model for the Philippines. However, Filipinos and Spanish Americans knew too little about each other. When asked about Filipinos' knowledge or ideas about Latin America during an interview held in 1960, Abad answered "casi nulas" (9). Elaborating on his answer, he added that it was very unlikely that Filipinos could point out Colombia on a world map. But instead of holding Filipinos responsible for this lack of knowledge, Abad suggested that the Philippines' isolation from Latin America could very well be attributed to United States' long domination of the Philippines. Although the interview, published in Colombian newspaper El Tiempo, was presumptuously titled 
"El español obtuvo en Filipinas clara victoria sobre el inglés," Abad's reports on student opposition against the required university credits in Spanish and the decreasing number of speakers of Spanish shed light on the language's imminent death and the clear victory of English in the Philippines. Even the interviewer, Colombian poet and journalist Dolly Mejía, remarks that despite "su correctísimo castellano," Abad could not help but reveal what she describes as "su innegable acento del inglés predominante" (9).

Instead of spending time and energy praising Spanish or celebrating its survival in the Philippines, throughout the 1950s Abad sought to change teaching methodologies for the language by working on manuals and lecturing on more effective ways to teach it. Moreover, he created the National Federation of Spanish Teachers, and in 1957, he travelled to the United States to learn about modern methodologies for the teaching of foreign languages (García xvii). By the time he was interviewed by Dolly Mejía, Abad had high hopes for the "formidable" campaign in favor of teaching Spanish. According to him, "La batalla está ganada, gracias a la firmeza de la Academia y a los sentimientos hispanófilos del presidente Carlos $P$. García" (9). Following Abad, pedagogies for Spanish language teaching had to catch up with laws that already paved the way for its dissemination or at least its preservation in the Philippines.

In 1960, Abad travelled to Bogotá, Colombia, to attend the Third Annual Congress of Academies of the Spanish Language and tellingly, he delivered a lecture titled "La enseñanza del español a extranjeros que no lo hablan." The gist of this paper was to communicate to his peers in corresponding Academies that Spanish in the Philippines was nearly dead and that it needed to be taught as a foreign language. Instead of expressing the Philippines' pride as the only Hispanophone nation in Asia, he emphasized that Filipino students barely knew Spanish: "Entre estos estudiantes 'que no hablan el español' hay que contar a los filipinos" (521). Rather than making Filipinos feel alienated, the result of continuing to teach Spanish would be, according to Abad, quite the contrary: it would attract more foreigners to the Philippines' rich culture. He affirmed: 
debemos -y está dentro de nuestras atribuciones-contribuir a que el conocimiento de nuestro idioma común sea más fácil para el extranjero que quiera acercarse a nosotros y participar en el caudal de ideas que atesora la cultura hispánica, y esto solo puede lograrse mediante una más efectiva didáctica de nuestra lengua [...] no bastan ya, para las urgencias del momento, las gramáticas al uso. Lo urgente en estos momentos no es saber las reglas a que se sujeta el habla sino el habla misma. (522, emphasis mine)

Reminiscent of the school teacher in Noli me tangere, Abad assures that the most effective methodology for teaching Spanish as a foreign language is focusing on conversation, not on memorization of grammar rules. Moreover, it is worthwhile to point out that in the above passage Abad refers to Spanish as "nuestro idioma común" and "nuestra lengua." In this view, Filipinos would be learning Spanish as a foreign language, but in doing so, they would nevertheless be recovering it as a lost heritage that always already belonged to them.

As a representative of the Philippines, Abad felt the need to alert his peers in the Academies of the Spanish Language about two ideas that had been proposed in 1959 by Hispanophone diplomats at a meeting held in Paris. Firstly, to create an "Alianza de la Lengua Española," which Spanish American nations would support. Through this alliance, various centers would be established throughout the Philippines for the teaching of Spanish and the promotion of cultural events. Secondly, a suggestion was made to create schools in the Philippines that would symbolically be named after Spanish American nations (Abad, “Doc E-5” 194-95). Although these ambitious proposals were not being implemented and did not apparently come to fruition, by mentioning them at the Third Congress of the Academies of the Spanish Language, Abad was uttering an urgent call for members of Spanish American Academies to support the teaching of Spanish in the Philippines. He was trying to turn the pro-Hispanist cause in the Philippines into a truly transpacific endeavor.

Surely enough, after the conference, Abad did keep in touch with various Spanish American attendees. Among them, his most significant contact was Félix Restrepo, S. J., President of the Colombian Academy of Language 
(the first Academy to be established in Spanish America) and founder of Instituto Caro y Cuervo (an important cultural center for the promotion of Spanish linguistics and Spanish-language literatures). In February 1961, Abad wrote a letter to Restrepo, proposing the creation of an international network of Hispanophone scholars. Echoing his own view regarding the Philippines' unfortunate isolation from Latin America, he added: "Estoy tropezando con que no conozco casi a nadie en Hispanoamérica, y nuestros colegas académicos no parecen tener idea de cómo se traduciría el plan" (Abad Papers). Fortunately, while Abad hoped to establish closer ties with Spanish America, the Instituto Caro y Cuervo happened to be considering ways to extend its presence and influence internationally. Just a few years prior, in 1957, the Instituto had created the still operating Andrés Bello Seminar, with the support of the Organization of the American States, for the advancement of literary and linguistic research as well as Spanish language pedagogy. Thus, in 1962, Abad was again in contact with members of the Instituto to make the necessary arrangements for the first Filipino candidate for the Andrés Bello Seminar. ${ }^{15}$

For his part, Abad continued to publicly rethink how Spanish was taught in the Philippines. In 1962, he gave a lecture at the library of Manila-based organization Solidaridad Hispanofilipina, titled "La enseñanza del español en Filipinas: sus males $y$ sus remedios," in which he explained that the failure of Spanish was not the result of a lacking pro-Hispanist cause, but of the rather outdated teaching methodologies. He addressed anti-Hispanist attacks, but did not recur to a predictable defense of the language's historical and patriotic value. Abad insisted that instead of enforcing the memorization of poems by Rizal or explaining grammar rules, students needed to be taught how to respond in simple phrases. Put differently, they had to be taught how to communicate in the language and not use it as a shortcut for cultivating patriotic sentiment.

Moreover, beyond offering practical advice for teaching Spanish, Abad articulated his opposition to what he called "las doctrinas monolingüistas norteamericanas" (10). Monolingualism, he claimed, was in direct opposition to the Philippines' cultural and historical progress. To contrast the divi- 
sive language policies promoted during and after the United States colonial rule, he referred to the inherent diversity in "Hispanidad," among which the former colonizer, Spain, was not the essence: "En la Hispanidad, España es sólo una parte, importantísima si queréis, pero la mayor es toda Hispanoamérica, desde Cuba, Puerto Rico, México y las Repúblicas del Centro hasta la América del Sur; o sea, un conjunto de 20 países independientes con cerca de 200 millones de habitantes" (11). In a contemporaneous report, titled "El problema de la lengua nacional en Filipinas," Abad more clearly reframed Spanish as a language that allowed the Philippines to reconnect with Spanish America. ${ }^{16}$ Abad observes:

la experiencia señala un camino indudablemente matizado de conveniencia, pero esta conveniencia tiene una significación nacional: formar parte del grupo hispanoamericano, el cual, mientras nos ayuda a realizar nuestras ambiciones en el campo internacional, también contribuye a destacar una personalidad cuyos contornos deseamos dibujar frente a los demás pueblos de la tierra. Esta es la verdadera posición del hispanismo y los hispanistas filipinos. (22, emphasis mine)

Abad's plan was to further the dissemination of Spanish in the Philippines, but not as a prestigious or divine language that inspired nostalgia for a past empire. Taking Recto's dictum on the diplomatic advantage of retaining Spanish a step further, Abad sought to convince his peers that teaching the language as one that already belonged to them would help the Philippines to reconnect with a living and growing Hispanophone community, especially the vast Spanish American group across the Pacific.

\section{Conclusion: Revisiting "el Babel nuestro"}

Some defenders of the Spanish language in the Philippines, including Recto in his youth, looked back, quite literally, at "Mother" Spain. Others often affirmed, and still do, that the very idea of the Philippines was molded in Spanish: Rizal wrote in Spanish; the first Filipino Constitution, ratified in Malolos in 1899, was published in Spanish; and José Palma's quintessentially patriotic poem of 1899, which then served as the lyrics to the national anthem, was also composed in Spanish. Nevertheless, in this article, I have examined two alternative frameworks for further dissemination of the language. For 
Recto, the decline of Spanish in the national context was lamentable as it resulted in a huge loss for future Filipinos who desired to have access to their nation's origins, but also because it signified an impediment to the language's transpacific trajectory. Abad insisted on keeping Spanish in the curriculum, but neither by employing methodologies for the instruction of an extinct language (as in the case of Latin) nor framing it as a language that is part of a colonial heritage. Rather, he envisioned teaching it as a living and breathing language of day-to-day life despite it being spoken by a numerical minority in the Philippines. His visit to Colombia in 1960 only made him more aware of how much insight Filipinos could gain by communicating and identifying with Spanish Americans. ${ }^{17}$

At present, the Spanish language in the Philippines not only remains a point of access to the nation's history, but it has also been linked, according to Mauro Fernández and José del Valle, to at least two immediate economic advantages: on the one hand, it potentially enables Filipinos to work at call-centers and other international business operations outsourced to the Philippines, and on the other hand, it renders Filipinos who choose to migrate to the United States more competitive vis-à-vis the Latino population there. Following Fernández and del Valle, these incentives are "deeply pragmatic and in no way linked to identity" (332). However, the latter incentive interestingly projects Filipinos alongside Latinos, who also tend to possess varying degrees of fluency of and intimacy with the Spanish language. Perhaps, as in the case of Latinos in the United States, it may be relevant, more precise even, to refer to Spanish in the Philippines as a kind of heritage language. Or perhaps, following critic Andrea Gallo, who specializes in contemporary Hispanophone Filipino writers, Spanish should be characterized more often as a "familiar" language (530). After all, it is seldom a fully foreign language in the Philippines.

If multilingual poet Federico Espino Licsi declared, around forty years ago, that Filipinos should not be forced to learn Spanish, that they should first study "el Babel nuestro" before learning "el Babel extranjero," then it seems appropriate to revisit the definitions of "nuestro" and "extranjero." In the end, to admit that Spanish is, or rather has become, a foreign language in the 
Philippines does not mean that it cannot also be taught as a language that still belongs to Filipinos, the same way it certainly belongs to many millions of people across the Pacific and the Atlantic. 
1. I would like to thank Ulrich E. Bach, Sean Manning, and the two anonymous reviewers for their suggestions in earlier drafts of this article. I also thank Elizabeth Medina for sharing her profound insights after reading Espino Licsi's 1979 lecture. Last but not least, I thank Wesleyan University and the National Endowment for the Humanities for funding my research travels to the Philippines and Colombia in the summers of 2017 and 2018, respectively.

2. Translating poetry from the so-called "Third World" was part of Espino Licsi's ongoing projects. In 1975, he edited the volume Mga tulang Afro-Asyatico. In 1981, he co-edited, with Paula Espino, the volume Ang Panulaan ng Afrika at Timog Silangang Asya. These are listed in the bibliography with the order of his last names interchanged. As Rocío Ortuño Casanova notes, in Spanish the Filipino poet published as Espino Licsi and in English and Filipino languages as Licsi Espino or Licsi Espino Jr. ("Espino Licsi” 63).

3. According to Espino Licsi, learning Spanish should only be mandatory for students of Philippine history, diplomacy, or Philippine Studies (19).

4. Some of Espino Licsi's poetry publications at the time, which were entirely or partially in Spanish, include In Three Tongues: A Folio of Poems in Tagalog, English and Spanish (1963), Caras y caretas del amor (1967), Burnt Alphabets: Poems in English, Tagalog and Spanish (1969), Ave en jaula lirica / Bird in the Lyric Cage (1970), and Latigazos de luz (1977). For a close reading of poems from these and later collections by Espino Licsi, focusing on the evolution of his attitude toward Spain and Spanish literature, consult Ortuño Casanova's 2016 article.

5. A report from 1872 states that out of 125,000 students enrolled in public primary schools in Luzon and Visayas, only thirty percent could read Spanish and less than one percent could actually speak it (qtd. in Hardacker 19). According to the 1903 United States Census, out of a population of around six million people, only about one percent of the population had received "superior education" and was deemed to be "undoubtedly" fluent in Spanish (Rafael 197, n. 9). Reminding us of the historical background that also contributed to the reduced number of speakers in the Philippines at the end of the Spanish colonial period, Jorge Mojarro points out: "The reason Spanish instruction was not that forthcoming from the friars was partly practical: it was easier that a foreign person learn the indigenous language rather than oblige his adopted community of thousands to learn his language. This was also quite logical. Moreover, the missionaries carried out a thorough documentation of the Filipino languages, relying on grammars, dictionaries, and translations. If later on they used this knowledge to appropriate power, this was something more circumstantial all told." 
6. For a summary and commentary on the royal decrees prior to 1863 which repeatedly stipulated Spanish as the language of instruction in the Philippines and yet failed, see Hardacker 10-13 and Fernández 364-66.

7. After the teacher greets the Spanish friar who has summoned him in Spanish, he is reprimanded: "No me uses prendas prestadas; conténtate con hablar tu idioma $y$ no me eches a perder el español, que no es para vosotros" (99). Miguel A. Bernad observes that this scene from the novel demonstrates, "first, the opposition of the friars (or at least of many of them) to the teaching of Spanish; and second, the contempt that many of the friars openly showed towards the native Filipino" (223).

8. I gather a summary of these laws and the public responses they generated from Rodao 105 and Fernández 373.

9. For a comprehensive analysis of poems dedicated to Spain during the US rule of the Philippines, see Ortuño Casanova's 2014 article.

10. Darío's promotion of an "América nuestra," with which he foremost meant an "América española" (102-03), has its limitations, yet it should be interpreted primarily as a strategic response to the rise of the United States as the new empire.

11. As a literary writer Recto is mostly remembered for his "Elogio del castellano," his poetry collection Bajo los cocoteros (1911) as well as his plays "La ruta de Damasco" (1914) and "Solo entre las sombras" (1917).

12. Recto said the following in a 1942 radio speech: "As you doubtless are aware, Japanese and Tagalog have been declared the two official languages in the Philippines. It is only logical that the study of Japanese should be enjoined upon us" (vol. 5,306$)$.

13. Not without trouble, this voyage was supported by the Franco dictatorship, which sought to promote Hispanism within its former colonies (Espiritu 169).

14. Abad's literary works include the novels El último romántico (1927), La oveja de Nathan (written in 1929 and published in a bilingual Spanish and English edition in 2013), El campeón (written in 1940 and published by Instituto Cervantes in Manila in 2013), and La vida secreta de Daniel Espeña (1960).

15. In July 1962, Abad wrote a letter to Rafael Torres Quintero, Secretary of the Third Congress of Academies of the Spanish Language, introducing Antonio María Cavanna, the first Filipino candidate for the seminar, as "uno de los más decididos campeones del hispanismo en Filipinas" (Abad Papers).

16. This report can be found at the Library of Instituto Caro y Cuervo. While the file does not contain paratextual information regarding when Abad wrote it, some references mentioned in the text itself indicate that it was either in 1962 or 1963.

17. For an intimate account of the cultural and historical ties between the Philippines and Spanish America, see Elizabeth Medina's Sampaguitas en la cordillera: reen- 
cuentro con Filipinas en Chile (2005). The book narrates how Medina embarked on a journey to find out the circumstances that led to the execution of her paternal grandfather, Emilio Medina Lazo, in 1945, in Ilocos Norte, as well as her experience discovering "el verdadero sentido de ser filipina" (8) by reading Spanish American literature and history, and living in Chile, where she still resides and works as translator and writer. 


\section{Works Cited}

Abad, Antonio M. Antonio M. Papers. TS. University of the Philippines Library. Box 1. “Doc E-5.” Tercer Congreso de Academias de la Lengua Española: actas y labores. Bogotá: Academia Colombiana de la Lengua, 1960. pp. 191-99.

. El campeón. Edited by Salvador García and Luisa Young, Instituto Cervantes de Manila, 2013.

. "El español obtuvo en Filipinas clara victoria sobre el inglés." Interview by Dolly Mejía. El Tiempo August 4, 1960, 9.

"El problema de la lengua en Filipinas." n/d. Unpublished report. Instituto Caro

y Cuervo Library, Bogotá, 2018, pp. 1-47.

"La enseñanza del español a extranjeros que no lo hablan." Tercer Congreso de

Academias de la Lengua Española: actas y labores. Bogotá: Academia Colombiana de la Lengua, 1960, pp. 519-24.

"La enseñanza del español en Filipinas: sus males y sus remedios." 27 November,

1962, Quezon City, Philippines. Unpublished conference paper. Instituto Caro y Cuervo Library, Bogotá, 2018, pp. 1-18.

. La oveja de Nathan: una novela filipina / Nathan's sheep: a Philippine Novel.

Translated by Lourdes Castrillo Brillantes. Edited by Lilia Ramos de León, Edgardo Tiamson Mendoza, and Isaac Donoso Jiménez, Makati City: Georgina Padilla y Zóbel, Filipinas Heritage Library and Ayala Foundation, 2013.

Bernad, Miguel A. “The Schoolmaster's Predicament: Rizal's Dialogue on

Education." Budhi: A Journal of Ideas and Culture, vols. 2 \& 3, 2000, pp. 221-30.

Darío, Rubén. Páginas escogidas. Edited by Ricardo Gullón, Madrid: Ediciones

Cátedra, 2005.

Donoso, Isaac. "El español y la política lingüística filipina." Historia cultural de la lengua española en Filipinas: ayer y hoy. Edited by Isaac Donoso, Editorial Verbum, 2012, pp. 429-57.

Donoso, Isaac and Heidi Macahilig-Barceló. "El español y la historia de la lectura en Filipinas." Historia cultural de la lengua española en Filipinas: ayer y hoy. Edited by Isaac Donoso, Editorial Verbum, 2012, pp. 385-427.

Espino Licsi, Federico. “Filipinas, el idioma español y el Tercer Mundo.” Punto y coma. Departamento de Lenguas Europeas, Universidad de Filipinas, 1980, pp. 18-23.

Espiritu, Augusto. "American Empire, Hispanism, and the Nationalist Visions of Albizu, Recto, and Grau.” Formations of Unites States Colonialism. Edited by Alyosha Goldstein. Duke UP, 2014, pp. 157-79.

Fernández, Mauro. "The Representation of Spanish in the Philippine Islands.” $A$ Political History of Spanish: The Making of a Language. Edited by José del Valle. Cambridge UP, 2013, pp. 364-79. 
Fernández, Mauro and José del Valle. "Introduction to the Making of Spanish Beyond Spain and the Americas." A Political History of Spanish: The Making of a Language. Edited by José del Valle. Cambridge UP, 2013, pp. 327-34.

Gallo, Andrea. "El sino actual de la literatura filipina en español." Historia cultural de la lengua española en Filipinas: ayer y hoy. Edited by Isaac Donoso, Madrid: Editorial Verbum, 2012, pp. 529-49.

García, Salvador. Introduction. El campeón, by Antonio M. Abad, Instituto Cervantes de Manila, 2013, pp. ix-liii.

Gonzalez, Andrew. Language and Nationalism: The Philippine Experience Thus Far. Ateneo de Manila UP, 1980.

Hardacker, Erin P. “The Impact of Spain’s 1863 Educational Decree on the Spread of Philippine Public Schools and Language Acquisition." European Education, vol. 44, no. 4, 2012, pp. 8-30.

Licsi Espino, Federico, editor. Mga tulang Afro-Asyatiko. Alemar-Phoenix Publishing House, 1975.

Licsi Espino, Federico and Paula L. Espino, editors. Ang Panulaan ng Afrika at Timog-silangang Asya. Soller Press \& Publishing House, 1981.

Medina, Elizabeth. Sampaguitas en la cordillera: reencuentro con Filipinas en Chile. Santiago: RIL Editores, 2006.

Mojarro, Jorge. "The Life and Times of Spanish in the Philippines." Business World Online, 3 July 2015. bworldonline.com/content.php?section=Weekender\&title=The-life-and-times-of-Spanish-in-the-Philippines\&id=110780.

Ortuño Casanova, Rocío. "Espino Licsi vs. Licsi Espino: cantos a la cultura española desde Filipinas.” Bulletin of Hispanic Studies, vol. 93, no. 1, 2016, pp. 63-80. "La representación de España en la poesía filipina en castellano de la época de ocupación americana: idealización, exotización y diferenciación.” Transmodernity, vol. 4. no. 1, 2014, pp. 154-67.

Peña, Wystan de la. “'Filipino' vs. 'Fil-Hispanic': The Politics of Appropriation and Assimilation in Philippine Cultural Identity Construction." Encuentro: Philippine-Spanish Friendship Day. Edited by Ma. Luisa T. Camagay, Spanish Program for Cultural Cooperation, 2008, pp. 101-13.

Quezon, Manuel L. "We must have a national language." Literature Under the Commonwealth. Edited by Manuel E. Arguilla, Esteban Nedruda, and Teodoro Agoncillo, Philippine Writers' League, 1940, pp. 23-30.

Rafael, Vicente L. The Promise of the Foreign: Nationalism and the Technics of Translation in the Spanish Philippines. Duke UP, 2005.

Recto, Claro Mayo. Complete Works of Claro M. Recto. 9 vols. Edited by Isagani R. Medina and Myrna S. Feliciano, Claro M. Recto Memorial Foundation, 1990. 
Rizal, José. Noli me tangere. Edited by Márgara Russotto. Biblioteca Ayacucho, 1982. Rodao, Florentino. "Spanish Language in the Philippines: 1900-1940." Philippine Studies vol. 45, no. 1, 1997, pp. 94-107. 